\title{
Prolactin-Rsal gene polymorphism in East Anatolian Red cattle in Turkey
}

\author{
Z. Sonmez \& M. Ozdemir ${ }^{\#}$ \\ Department of Animal Science, Faculty of Agriculture, Ataturk University, 25240 Erzurum, Turkey
}

(Received 14 January 2016; Accepted 15 December 2016; First published online 27 January 2017)

Copyright resides with the authors in terms of the Creative Commons Attribution 4.0 South African License.
See: http://creativecommons.org/licenses/by/4.0/za
Condition of use: The user may copy, distribute, transmit and adapt the work, but must recognize the authors and the South African Journ
Animal Science.

\begin{abstract}
Prolactin (PRL) plays an important role in regulating mammary gland development, secreting milk, and expressing milk protein genes; making it a potential genetic marker and a candidate gene for production traits in dairy animals. The aim of the study was to determine by Polymerase Chain Reaction-Restriction Fragment Length Polymorphism (PCR-RFLP) method the gene and genotype frequencies of PRL gene in native East Anatolian Red (EAR) cattle, which are raised as a genetic resource in Turkey. PCR-RFLP analysis involved the use of the Rsal restriction enzyme. Three patterns of fragments were obtained. The AA, AG, and GG genotype frequencies were $0.07,0.34$, and 0.59 in the cattle population, respectively. For Prolactin-Rsal (PRL-Rsal) polymorphism, the population was in Hardy-Weinberg equilibrium. Heterozygosity was found at a medium rate as 0.338 and the calculated $F_{I S}$ value was 0.072 .
\end{abstract}

Keywords: genetic resource, mammary gland, prolactin gene, PCR-RFLP

\#Corresponding author: ozdemirm@atauni.edu.tr

\section{Introduction}

Polymorphic genes involved in the secretion of milk are important as candidate genes, and could be used in indirect selection of livestock because of their relationships with quantitative traits (Miceikiene et al., 2006; Alipanah et al., 2008; Alfonso et al., 2012). Prolactin (PRL) plays an important role in regulating mammary gland development, expressing milk protein genes and secreting milk (Brym et al., 2005). Therefore, the PRL gene is potentially a strong genetic marker for the improvement of livestock. The gene consists of 5 exons and 4 introns, and is $10 \mathrm{~kb}$ in size, encoding the 199 amino acid in the BTA23 (Camper et al., 1984; Freeman et al., 2000; Dybus, 2002). PRL is secreted from the pituitary gland and cells, mainly the lymphocytes, and has an immunostimulatory effect and promotes autoimmunity (Orbach \& Shoenfeld, 2007).

Genetic polymorphism studies have been carried out on the bovine PRL gene sequences. The most important polymorphism was located and identified by Rsal endonuclease using PCR-RFLP (Mitra et al., 1995; Brym et al., 2005). These polymorphic structures have been studied by many researchers, who confirmed statistically significant associations between these polymorphic variants and milk production traits in cattle (Dybus et al., 2005; Brym et al., 2005; He et al., 2006; Alipanah et al., 2008; Mehmannavaz et al., 2009; Rorie et al., 2009; Alfonso et al., 2012; Boleckova et al., 2012; Ishaq et al., 2012; Akyuz et al., 2012; Akyuz \& Cınar, 2014; Ozkan Unal et al., 2015). It was suggested that PRL variants could be useful in direct selection programmes for improving milk traits in livestock (He et al., 2006; Alipanah et al., 2008; Rorie et al., 2009; Alfonso et al., 2012; Boleckova et al., 2012; Akyuz et al., 2012). Generally, the results showed that PRL-Rsal ${ }^{(+)}$allele effect was significant for milk and protein yield, where the PRL-Rsal(-) allele was unfavourable for milk and protein yield, but favourable for fat yield.

Table 1 presents the findings of various researchers, who reported allele frequencies in the PRL-Rsal region in buffalo and cattle breeds. The PRL-Rsal ${ }^{(+-)}$polymorphisms have been reported as $A / B$ or $A / G$ in some studies.

The EAR native cattle breed is genetically the most distant compared with other breeds because it is a native breed in the vicinity of the Near East, which is known as the first centre of domestication (Ozdemir \& Dogru, 2009; Dogru et al., 2012). The objectives of the present study were to determine PRL-Rsal polymorphism, and estimate the gene and genotype frequencies in native EAR cattle in Turkey. Determining the PRL-Rsal allele composition particular to the EAR breed would contribute to conservation efforts for this breed because it is raised as a valuable genetic resource. 
Table 1 Polymorphism of PRL-Rsal locus in various buffalo and cattle breeds

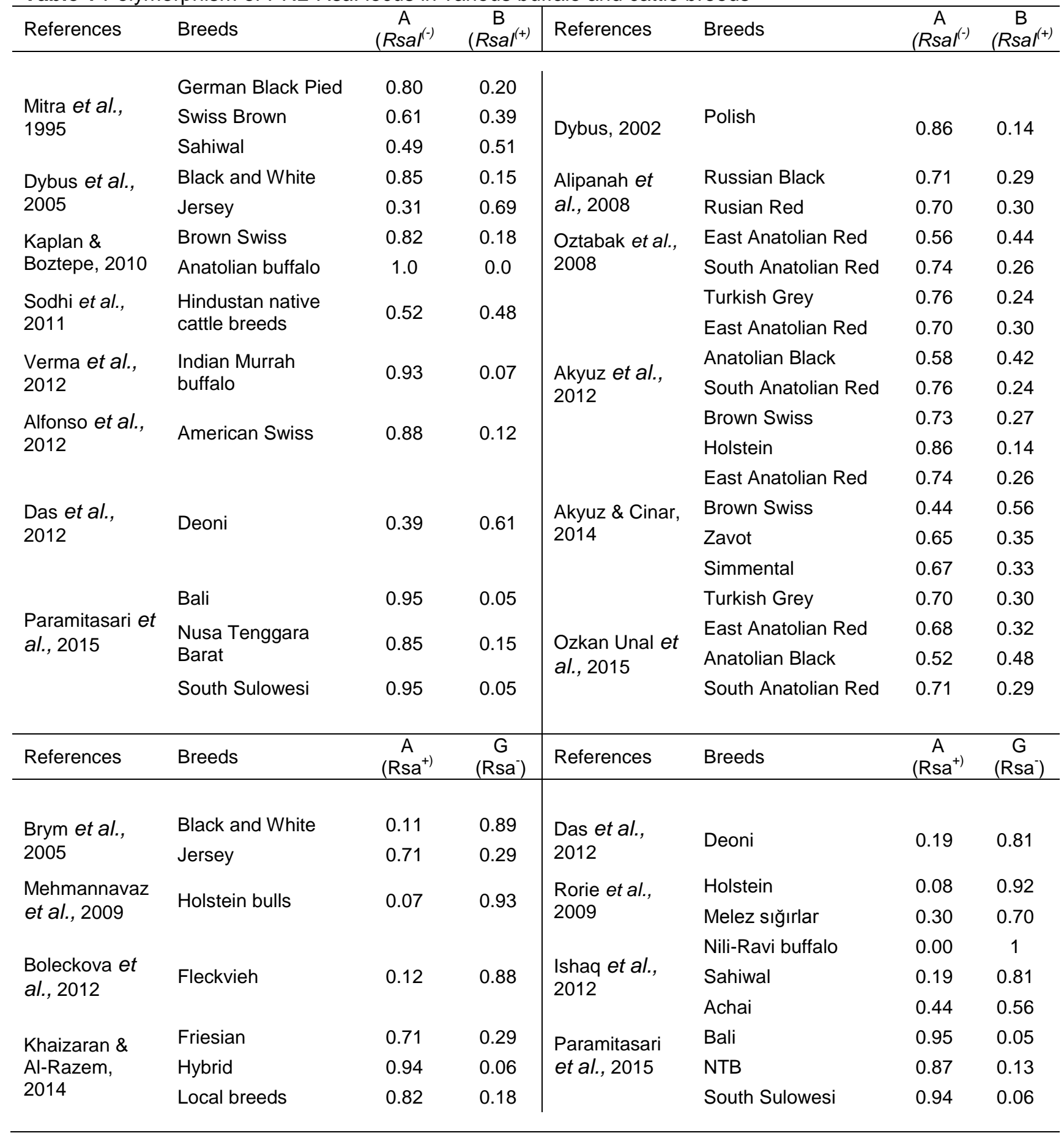

\section{Materials and Methods}

Blood samples were collected in a $10 \mathrm{ml}$ vacuum tube containing K3EDTA from the left jugular vein of 71 EAR cattle (17 bulls and 54 cows), which are maintained as a genetic resource in Eastern Anatolia, Turkey. Genomic DNA was extracted from whole blood samples using the Purgene kit (Gentra Systems, Plymouth, Minn., USA) and stored at $4{ }^{\circ} \mathrm{C}$.

For the PRL gene, PRL-Rsal Forward:5'-TTC ATG AAG CTG CTC ACC TG-3' and Reverse:5'- TGT GGT TGT TCA GCA TGA AGT-3' primers were designed from the National Centre for Biotechnology Information (NCBI) GenBank sequences (accession nos AB098480 and AF426315) using the Primer3 program (Rozen \& Skaletsky, 2000). Amplification reactions were performed in a final volume $20 \mu \mathrm{l}$ 
containing $1 \mu \mathrm{M}$ of each primer, 2,5 $\mu \mathrm{d}$ dNTP (D7595) (Sigma, St. Louis, Mo., USA), 0,5 U of Taq DNA polymerase (D1806) (Sigma, St. Louis, Mo, USA), approximately 50-100 ng of template DNA, $5 \mu \mathrm{l}$ of 10x PCR buffer (catalogue P2192) (Sigma, St. Louis, Mo, USA), $1 \mu$ of $25 \mathrm{mM} \mathrm{MgCl}_{2}$ and ddH2O. PCR amplifications were performed in $5 \mathrm{~min}$ at $94^{\circ} \mathrm{C}, 30$ cycles of $45 \mathrm{~s}$ at 94,61 and $72{ }^{\circ} \mathrm{C}$, which were followed by final extension at $72{ }^{\circ} \mathrm{C}$ for $5 \mathrm{~min}$. The amplified products were digested by using $R s a /$ at $37^{\circ} \mathrm{C}$ overnight. To genotype animals for the RFLP, in related region, 8-10 $\mu \mathrm{l} \mathrm{PCR} \mathrm{reaction} \mathrm{mix} \mathrm{was} \mathrm{used} \mathrm{for} \mathrm{restriction}$ enzyme digestion, which was performed in $15 \mu \mathrm{l}$ volume in $0.2 \mathrm{ml}$ sterilized Eppendorf tubes. Each $15 \mu \mathrm{l}$ digestion mix was electrophoresed in $2.5 \%$ agarose gel at $40 \mathrm{~V}$ for $2.5 \mathrm{~h}$ and DNA was visualized by staining with ethidium bromide under UV light. A standard DNA marker (P1473) (Sigma, St. Louis, Mo., USA) was used.

For each animal, PRL allele frequencies were determined by gene counting. The chi-square $\left(X^{2}\right)$ test was used to check whether the population was in H-W equilibrium by GenAIEx 6.5 program (Peakall \& Smouse, 2012).

\section{Results and Discussion}

PRL gene polymorphisms were investigated by the PCR-RFLP method in native EAR cattle raised as genetic resource in Turkey. The genotyping procedure revealed three patterns of fragments of $210 \mathrm{bp}$ (allele G) and 120 and $90 \mathrm{bp}$ (allele A) for the PRL-Rsal region (Figure 1).

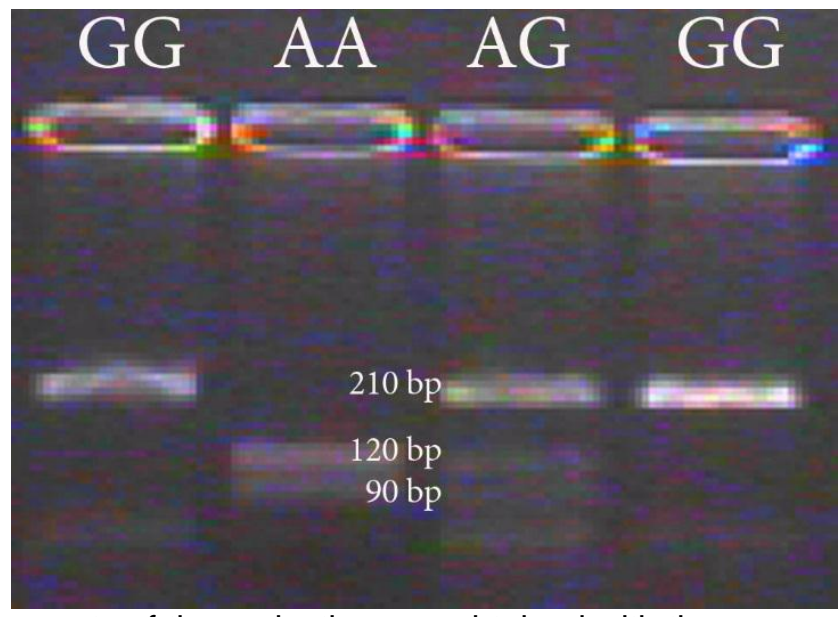

Figure 1 Polymorphism fragments of the prolactin gene obtained with the enzyme $R$ sa I in agarose gel using 2.5\% with ethidium bromide. Lane 1 and 4: genotype GG (210 bp), Lane 2: genotype AA (120 and $90 \mathrm{bp}$ ) and Lane 3: genotype AG (10, 120, and $90 \mathrm{bp})$

Genotype frequencies and allelic frequencies of native EAR cattle are presented in Table 2 and Figure 2 , respectively.

Table 2 Allelic and genotypic frequencies of the Prolactin-Rsal polymorphism, heterozygosity and fixation index and statistical test result for Hardy-Weinberg equilibrium.

\begin{tabular}{|c|c|c|c|c|c|c|c|c|}
\hline \multicolumn{3}{|c|}{ Genotype } & \multicolumn{2}{|c|}{ Allele frequency } & \multicolumn{3}{|c|}{ Heterozygosity and fixation index } & \multirow{2}{*}{$\begin{array}{l}\mathrm{H}-\mathrm{W} \\
X^{2} \text { test }\end{array}$} \\
\hline AA & $A G$ & $\mathrm{GG}$ & G & A & Ho & $\mathrm{He}$ & $\mathrm{F}_{\text {is }}$ & \\
\hline $0.07(5)$ & $0.34(24)$ & $0.59(42)$ & 0.76 & 0.24 & 0.338 & 0.364 & 0.072 & 0.38 \\
\hline
\end{tabular}




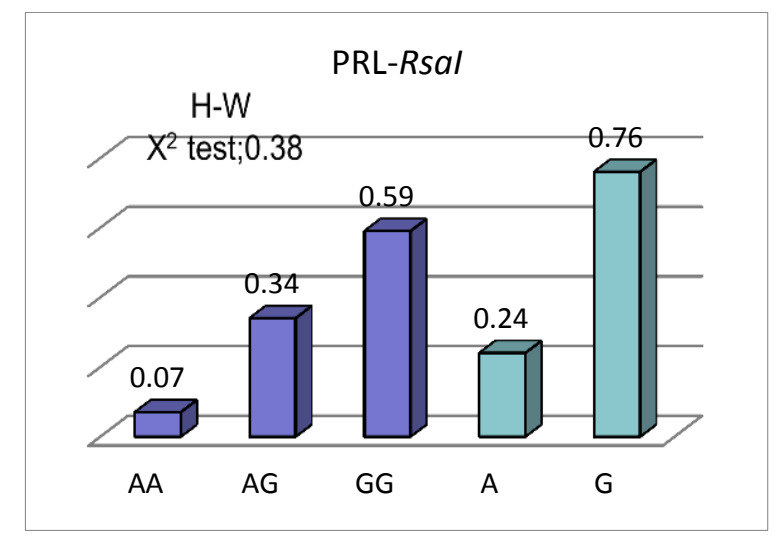

Figure 2 Prolactin-Rsal polymorphism and allelic and genotypic states in native East Anatolian Red cattle

AA, AG, and GG genotype frequencies obtained in PRL-Rsal were 0.07, 0.34 and 0.59 , respectively. $G$ allele (PRL-Rsal $\left.{ }^{(-)}\right)$frequency was 0.76 , and was found to be more prominent than the $A$ allele. This result is similar to the findings of earlier researchers, who reported genotype frequencies in various regions of the world with different breeds and sample sizes (Dybus et al., 2002; Miceikienè et al., 2006; Alipanah et al., 2008; Mehmannavaz et al., 2009; Rorie et al., 2009; Kaplan \& Boztepe 2010; Sodhi et al., 2011; Alfonso et al., 2012; Boleckova et al., 2012; Das et al., 2012; Ishaq et al., 2012). However, Dybus et al. (2005) found a lower $\mathrm{G}$ allele frequency in Jerseys.

PRL-Rsal ${ }^{(-)}$allele (gene) frequency in previous studies on EAR cattle had the greatest frequency and the population was in $\mathrm{H}-\mathrm{W}$ equilibrium $(P>0.05)$ (Oztabak et al., 2008; Akyuz \& Cinar, 2012; Ozkan Unal et al., 2015). These results were similar to those of the present study.

Heterozygosity was found at a medium rate as 0.338 for PRL-Rsal polymorphism and the population was in H-W equilibrium (Table 2). Heterozygosity was 0.186 in EAR (Akyuz et al., 2012), 0.038 in Holstein, and 0.33 in Jersey cattle (Brym et al., 2005). Dybus et al. (2005) found 0.28 in Black and White and 0.43 in Jersey. The $F_{I S}$ value for the region was 0.072 in EAR population. According to this value, despite the small number of the EAR population as a genetic resource, homozygosity was at a low rate.

Molecular genetic techniques have allowed the use of DNA markers associated with various economic traits in promoting efficient selection and breeding strategies of livestock. It is now generally accepted that the PRL gene plays a key role because it regulates mammary gland development, milk protein genes and milk secretion (Alipanah et al., 2008; Othman et al., 2011) Thus, the PRL gene may be a strong candidate gene for economically important production traits. However, in this study, the relationships between PRLRsal genotypes and production traits were not established because of lack of records of native EAR cattle.

\section{Conclusion}

PRL-Rsal polymorphism was investigated by the PCR-RFLP method. It showed the allelic and genotypic frequencies of the PRL-Rsal polymorphism region, heterozygosity and fixation index in the native EAR cattle breed; which are raised as a genetic resource in Turkey. For PRL-Rsal polymorphism, heterozygosity was found at a medium rate and the native EAR cattle population was in $\mathrm{H}-\mathrm{W}$ equilibrium $(P$ $>0.05$ ). In this study, the relationships between genotypes and production traits were not established on native EAR cattle. However, it is now generally accepted that PRL plays a key role in the secretion of milk, in regulation of mammary gland development, and the expression of milk protein genes of cattle. Thus, PRL may be a strong candidate gene for economically important production traits. Associations between PRL gene polymorphism and economic traits for the EAR population should be investigated further and evaluated for marker-assisted selection in large numbers of animals, which are required for such studies.

\section{Acknowledgements}

The authors gratefully thank Ataturk University Research Foundation (Project no 2011/335) for financial support.

\section{Authors' contributions}

This article was extracted from SZ's Master of Science thesis. OM wrote the manuscript and was responsible for drafting and submitting it. 


\section{Conflict of Interest Declaration}

None of the authors of this work has a financial or other relationship with people or organisations that could influence inappropriately or bias the contents of this paper.

\section{References}

Akyuz, B. \& Cinar, M.U., 2014. Analysis of prolactin and kappa-casein genes polymorphism in four cattle breeds in Turkey. Ann. Anim. Sci. 14, 799-806.

Akyuz, B., Agaoglu, K.O. \& Ertugrul O., 2012. Genetic polymorphism of kappa-casein, growth hormone andprolactin genes in Turkish native cattle breeds. Int. J. Dairy Technol. 65, 38-44.

Alfonso, E., Rojas, R., Herrera, J.G., Ortega, M.E., Lemus, C., Ruiz, J., Pinto, R. \& Gómez, H., 2012. Polymorphism of the prolactin gene (Prl) and its relationship with milk production in American Swiss cattle. Afr. J. Biotechnol. 11, 7338-7343.

Alipanah, M., Kalashnikova, L.A. \& Rodionov, G.V., 2008. Kappa-casein and Prl-Rsal genotypic frequencies in two Russian cattle breeds. J. Anim. Vet. Adv. 6, 813-815.

Boleckova, J., Matejickova, J., Stipkova, M., Kyselova, J. \& Barton, L., 2012. The association of five polymorphisms with milk production traits in Czech Fleckvieh cattle. Czech. J. Anim. Sci. 57, 45-53.

Brym, P., Kaminski, S. \& Wojcik, E., 2005. Nucleotide sequence polymorphism within exon 4 of the bovine prolactin gene and its associations with milk performance traits. J. Appl. Genet. 45, 179-185.

Camper, S.A., Luck, D.N., Yao, Y., Woychik, R.P., Goodwin, R.G., Lyons R.H. \& Rottman F,M., 1984. Characterization of the bovine prolactin gene. DNA, 3, 237-249.

Das, N.D., Hatkar, D.N., Hari, V.G.S., Srinivas, B.V., Kaliaperumal, R., Reddy, O.A. \& Krishnamurthy, L., 2012. Genetic polymorphisms of exons 3 and 4 of Prolactin (Prl) gene in Deoni cattle breed and their association with milk production traits. Int. J. Livest. Res. 2, 120-126.

Dogru, U., Ozdemir, M., Soysal I.M. \& Topal M., 2012. Determination of genetic distance between East Anatolian Red, Brown Swiss, Holstein and Simmental breeds of cattle using polymorphic systems. J. Appl. Anim. Res. 33, 145148.

Dybus, A., 2002. Associations of growth hormone $(\mathrm{GH})$ and prolactin (Prl) genes polymorphisms with milk production traits in Polish Black-and-White cattle. Anim. Sci. 20, 203-212.

Dybus, A., Grzesiak, W., Kamieniecki, H., Szatkowsk, I., Sobek, Z., Blaszczyk, P., Czerniawska, P., E., Zych, S. \& Muszynska, M. 2005. Association of genetic variants of bovine prolactin with milk production traits of Black-andWhite and Jersey cattle. Arch. Tierzucht. 48, 149-156.

Freeman, M.E., Kanyıcska, B., Lerant, A. \& Nagy, G., 2000. Prolactin: Structure, function and regulation of secretion. Physiol. Rev. 80, 307-317.

He, F., Sun, D., Yu,Y., Wang, Y. \& Zhang, Y., 2006. Association between SNPs within prolactin gene and milk performance traits in Holstein dairy cattle. Asian Austral. J. Anim. Sci. 19, 1384-1389.

Ishaq, R., Suleman, M., Riaz, N. M., Yousaf, M., Shah, A. \& Ghafoor, A., 2012. Prolactin gene polymorphism in Nili-Ravi buffaloes inrelation to Sahiwal and Achai cattle. Int. J. Dairy Technol. Doi:10.1111/j.1471-0307.2012.00875.x

Kaplan, S. \& Boztepe, S., 2010. The determination of prolactin gene polymorphism using PCR-RFLP method within indigenous Anatolian Water Buffalo and Brown Swiss, 2nd International Symposium on Sustainable Development, 8-9 2010, Sarajevo, pp 168-173.

Khaizaran, Z.A. \& Al-Razem, F., 2014. Analysis of selected milk traits in Palestinian Holstein-Friesian cattle in relation to genetic polymorphism. J. Cell Anim. Biol. 8, 74-85.

Mehmannavaz, Y., Amirinia, C., Bonyadi, M. \& Torshizi, R.V., 2009. Effects of bovine prolactin gene polymorphism within exon 4 on milk related traits and genetic trends in Iranian Holstein bulls. Afr. J. Biotechnol. 8, 4797-4801.

Miceikiene, I., Peciulaitiene, N., Baltrenaite, I., Skinkyte, R. \& Indriulyte, R., 2006. Association of cattle genetic markers with performance traits. Biologija 1, 24-29.

Mitra, A., Schlee P., Balakrishnan C.R. \& Pirchner, F., 1995. Polymorphism at growth hormone and prolactin loci in Indian cattle and buffalo. J. Anim. Breed. Genet. 112, 71-74.

Orbach, H. \& Shoenfeld, Y., 2007. Hyperprolactinemia and autoimmune diseases. Autoimmun. Rev. 6, 537-542.

Othman, O.E., Zayed, F.A., Ali, A.G. \& El-Rahman M.R.A., 2011. Genetic polymorphism of three genes associated with milk trait in Egyptian buffalo. J. Genet. Eng. Biotechnol. 9, 97-102.

Ozdemir, M. \& Dogru U., 2009. Determination of phylogenetic relationships of Turkish native cattle breeds with other cattle breeds using mitochondrial DNA D-loop sequence polymorphism. Asian Austral. J. Anim. Sci. 22, 955-961.

Ozkan Unal, E., Kepenek E.Ş., Dinc H., Ozer F., Sonmez G., Togan I.Z. \& Soysal, M.I., 2015. Growth hormone (GH), prolactin (Prl), and diacylglycerol acyltransferase (DGAT1) gene polymorphisms in Turkish native cattle breeds. Turk. J. Zool. 39, 734-748.

Oztabak, K., Un, C., Tesfaye, D., Akis, I. \& Mengi, A., 2008. Genetic polymorphisms of osteopontin (OPN), prolactin (Prl) and pituitary-specific transcript factor-1 (PIT-1) in South Anatolian and East Anatolian Red cattle. Acta Agric. Scand. A, 58, 109-112.

Paramitasari, K.A., Sumantri, C. \& Jakaria., 2015. The genetic variability of prolactin and signal transducers and activators of transcription 5A (STAT5A) genes in Bali cattle. Media Peternakan, 38, 1-11. Doi:10.5398/ medpet.2015.38.1.1.

Peakall, R. \& Smouse P.E., 2012. GenAIEx 6.5: Genetic analysis in Excel. Population genetic software for teaching and research - an update. Bioinformatics 28, 2537-2539. 
Rorie, R.W. Howland, E.M. \& Lester, T.D.E., 2009. Evaluation of a polymorphism in the prolactin gene as a potential genetic marker for mastitis susceptibility and milk production. Arkansas, Department of Animal Science, http://arkansasagnews.uark.edu/1356.htm.

Rozen, S. \& Skaletsky, H.J., 2000. Primer3 on the www for general users and for biologist programmers. Krawetz S, Misener S, (eds). In Bioinformatics methods and protocols: Methods in molecular biology. Humana Press, Totowa, NJ, USA, pp 365-386.

Sodhi, M., Mukesh, M., Mishra, B.P., Parvesh, K. \& Joshi, B.K., 2011. Analysis of genetic variation at the prolactin-Rsal (Prl-Rsal) locus in Indian native cattle breeds (Bos indicus). Biochem. Genet. 49, 39-45.

Verma, A., Gupta, I.D. \& Gandhi, R.S., 2012. Genetic polymorphism in exon 3 of prolactin gene in Indian Murrah buffaloes. WJAS 4, 408-412. 